\title{
Hybrid network intrusion detection (withdrawal notice)
}

\section{David Tahmoush}

David Tahmoush, "Hybrid network intrusion detection (withdrawal notice)," Proc. SPIE 9074, Sensors, and Command, Control, Communications, and Intelligence (C3I) Technologies for Homeland Security and Homeland Defense XIII, 90740G (3 June 2014); doi: 10.1117/12.2050043

SPIE. Event: SPIE Defense + Security, 2014, Baltimore, MD, United States 


\section{Hybrid network intrusion detection (Withdrawal Notice)}

Proc. SPIE 9074, 90740G (2014); http://dx.doi.org/10.1117/12.2050043

Online Publication Date: 3 June 2014

Withdrawn from Publication: 27 August 2014

Conference Date: 5 May 2014

Conference Location: Baltimore, Maryland, United States

Conference Title: Sensors, and Command, Control, Communication, and Intelligence (C3I) Technologies for Homeland Security and Homeland Defense XIII

Conference Chairs: Edward M. Carapezza

D. Tahmoush

Univ. of Maryland (United States)

The paper has been withdrawn from the SPIE Proceedings at the author's request. 